\title{
Field evaluation of small scale interculture implement in grapevine yard
}

\author{
Muhammad Kazim Nawaz ${ }^{1}$, Zia-Ul-Haq ${ }^{1 *}$, Ali Imran ${ }^{2}$, Hamza Muneer \\ Asam $^{1}$, Talha Mehmood ${ }^{1}$, Sohail Raza Haidree ${ }^{1}$, Abdul Qadeer $^{1}$ and \\ Muhammad Kamran Shafi ${ }^{1}$ \\ 1. Faculty of Agricultural Engineering and Technology, PMAS-Arid Agriculture University, Rawalpindi 46300- \\ Pakistan \\ 2. Pakistan Council for Scientific and Industrial Research Laboratories Complex, Lahore 54600-Pakistan \\ *Corresponding author's email: ziaulhaquaf@gmail.com \\ Citation \\ Muhammad Kazim Nawaz, Zia-Ul-Haq, Ali Imran, Hamza Muneer Asam, Talha Mehmood, Sohail Raza Haidree, \\ Abdul Qadeer and Muhammad Kamran Shafi. Field evaluation of small scale interculture implement in grapevine \\ yard. Pure and Applied Biology. Vol. 9, Issue 4, pp2347-2355. http://dx.doi.org/10.19045/bspab.2020.90249
}

\begin{tabular}{llll}
\hline \hline Received: 02/12/2019 & Revised: 22/06/2020 & Accepted: 15/07/2020 & Online First: 17/07/2020
\end{tabular}

\section{Abstract}

Grapevine (Vitis vinifera L.) is one of the major fruit in Pakistan and its $70 \%$ of area lies in Baluchistan, Khyber Pakhtunkhwa and Pothwar region of Punjab while Baluchistan is the major contributor in country total production. Annual country production of grapevine is 122 thousand tons with average yield of 19 tons/ha against the potential yield of 25 tons/ha. Main cause of low productivity is due to heavy weed infestation. Effective weed control is vital, as weeds use most of space, sunlight, water and nutrients due to their fast growth habits. A mall-scale intercultural implement by means of three shapes of blades with treatment $\mathrm{T}_{1} \mathrm{~L}$-shape, treatment $\mathrm{T}_{2} \mathrm{C}$-shape and treatment $\mathrm{T}_{3} \mathrm{~J}$-shape blade, suitable for small farmers under existing field conditions was developed during 2018-19. Implement performance was evaluated at Arid University Research Farm Koont, Chakwal, North Punjab, Pakistan in grapevine yard. Field performance of implement was tested for weeding efficiency, plant damage, speed, depth, theoretical field capacity, effective field capacity, field efficiency, fuel consumption and operational cost. Data recorded was statistical analyzed using Randomized Complete Block Design. Software statistic 8.1 was used for ANOVA and treatment means were compared at 5\% level of probability. Treatment $\mathrm{T}_{1}$ with L-shaped blade had the better performance as compared to other shape of blades in grapevine yard.

Keywords: Blade; Shapes; Intercultural; Rotary; Weeds control

\section{Introduction}

Grape (Vitis vinifera L.) is one of the world's major fruits that has very old history. It has been praised in "The Holy Quran". The European grapevine is believed to have originated in the area between Black and Caspian seas, where it still grows wild. It is believed that it was introduced throughout the Europe and later by explorer to all continents [1]. Herbicides are increasingly applied in vineyards worldwide. In an experimental vineyard in Austria, it was examined the impacts of three within-row herbicide treatments (active ingredients: flazasulfuron, glufosinate, glyphosate) and mechanical weeding on grapevine root myorrhization [2].

A better understanding of side effects of different weed control methods within vineyard ecosystem would help to develop 
more ecologically sound viticulture management practices [3]. The aim of the current study was to examine non-target effects of chemical and mechanical weed control on soil biota and grapevine nutrition. Earthworms mycorrhizal fungi and also soil microorganisms have been shown to be affected by chemical herbicides, it was hypothesized that herbicide induced alterations would be evident through changes in plant as well as in the soil [4].

Manual weeding requires huge labour force and interpretations near about $25 \%$ of the total labor requirement. In India, this operation is commonly performed manually with cutlass or dig out that requires high labour input, very cloudy and time wasting process. Moreover, the labour requirement for weeding depends on weed plants, weed intensity, time of weeding, and soil moisture at the time of weeding and efficiency of worker [5]. Researcher reported that in weeding operation; recently power weeders are introduced with rotary tillage equipment having 3.7-5.5 $\mathrm{kW}$ capacity and engine weight of $300-400 \mathrm{~kg}$. These implements are not become popular due to clogging of weeds in between tines and intermediate cleaning is required when used in higher moisture content. Present pattern of row cropping concept widely adopted by Indian farmers and development of self-propelled sweep or drag type weeder is the need of the day. In this view, self-propelled small engine operated weeder is better option due to its medium cost and small size implying better manoeuverability in the small land holdings [6].

To investigate the rotary tillage operation because of its higher ability to mix, roll out and pulverize soil. The rotary weeder can be made to operate various working depths, widths and soil conditions. The rotating blades cut and mix the residues regularly throughout the working depth compared to any other mechanism. Weeders are mechanical implements which are used for weed removal [7]. Weeders was an implement used for weed deduction. Mechanical preparing is one of the prominent methods of weed removal. Smaller weeding implements normally known as moveable weeders are solely used for weed removal in agricultural fields, gardens etc. Unlike tractors, weeders are non-conventional as for as, the movement of labour is concerned. In promoting weeders especially considering the fact that the majority of growers are having small land. So they can hardly accomplish to pay for expensive tractors [8]. The designed and developed a tractor operated 3 rows turning weeder for red gram crop. The weeder was designed using computer supported design and a proto type was made-up. The operational parameters selected for the study were three forward speeds $2.0,2.5$ and $3.0 \mathrm{~km} \mathrm{~h}^{-1}$ and two rotary speeds of 210 and $240 \mathrm{rpm}$. Three types of blades were used in the rotary weeder tests i.e., L, C and J-type blades [9]. Scientist designed and advanced a ridge profile power weeder have $2.20 \mathrm{~kW}$ petrol-start kerosenerun engine. The weeding efficiency ranged from 74.47 to $93.89 \%$ and plant damage varied from $0.88-7.33 \%$ for different soilimplement interaction parameters combinations. Actual field capacity was $0.069 \mathrm{ha}^{-1}$. The performance index was observed to be maximum 192.34 in case of C- type blade and lowest 153.94 for flat- type blades [10]. The weeds are cut due to rotary action and deposited in the soil so that it works as biological manure. Implement is equipped with pneumatic wheels, so that it can easily move on road as well as on field. Negative draft helps to move the implement in forward direction. The impact of rotating blade on soil helps to create tangential thrust force to push the implement forward with negligible slippage [11]. Researchers concluded that during his experimentation that tractor operated L-shaped blades 
performs better as compared to $\mathrm{C}$ and $\mathrm{J}$ type blades in trashy conditions as they are more effective in killing weed and they do not pulverize the soil as much [12]. Keeping in view above cited statements, the objective of experiment was to test different shapes of intercultural blades in grapevine field to control weeds infestation and to increase yield.

\section{Materials and methods}

Present study was conducted for testing the performance of power operated manually propelled small scale intercultural implement. During experimentation, the performance was tested for available rotary weeder and locally developed small scale new intercultural implements with three different shapes of blades ( $\mathrm{L}, \mathrm{C} \& \mathrm{~J}$ ). The inter-culture implements were tested for following parameters in grapevine yard at university research farm koont-MandraChakwal-road.

Field parameters of soil before weeding operation

\section{Soil texture}

Soil samples were taken with help of auger from three difference location in the field. Soil texture of samples was measured before weeding operation. It was loam with electrical conductivity $0.81 \mathrm{dsm}^{-1}, \mathrm{pH} 7.27$, organic matter $0.53(\%)$, available phosphorus $5.8 \quad\left(\mathrm{mg} \quad \mathrm{kg}^{-1}\right)$, available potassium $120\left(\mathrm{mg} \mathrm{kg}^{-1}\right)$ and saturation 39 (\%).

\section{Moisture content}

Moisture content of soil sample was measured with help of gravimetric method. Three samples were collected from field and moisture content of those samples was measured. Average moisture content was $(9.85 \%)$. Moisture content in trial field was almost same because all the treatment blocks were taken from same field. Research result are in line with finding of other scientists 2014 who found moisture contents in the field was (7.7-12.13\%) [13].

\section{Bulk density}

Bulk density of soil sample was measured according to oven dry method. Samples were collected from three different places from field. The bulk density was calculated 2.5291 $\left(\mathrm{g} / \mathrm{cm}^{3}\right)$.

\section{Weeding efficiency}

It can be defined as the ratio between the number of weeds removed during weeding process to the number of weeds present in a unit area before weeding and expressed as a percentage.

The weeding efficiency of the intercultural implement was calculated by the following equation [14];

Weeding efficiency $=\frac{\mathrm{N} 1-\mathrm{N} 2}{\mathrm{~N} 1} \times 100$

Where;

$\mathrm{N}_{1}=$ Number of weeds existing per unit area before weeding operation.

$\mathrm{N}_{2}=$ Number of weeds calculated in same unit area after weeding operation.

\section{Plant damage}

It is the ratio of the number of grapevines destroyed after weeding operation in a unit area to the number of grapevine present before operation in the same unit area.

$\mathrm{R}=\frac{\mathrm{q}}{\mathrm{p}}$

Where;

$\mathrm{R}=$ Plant damaged $(\%)$.

$\mathrm{p}=$ Total number of grapevine per unit area before the weeding operation.

$q=$ Total number of grapevine damaged in the same unit area after the weeding.

\section{Field capacity}

The intercultural implement was tested on the experimented soil to calculate the field capacity. It is expressed the total area that a implement can cover per unit time can be calculated by using formula [13].

Field Capacity $(\mathrm{ha} / \mathrm{h})=\frac{66}{t} \times \frac{A}{10,000}$

Where;

$\mathrm{A}=$ Area covered $\left(\mathrm{m}^{2}\right)$,

$\mathrm{t}=$ Time taken in minutes 


\section{Depth of operation}

After the operation of implement in field, depth of cut was measured randomly with the help of scale from five different places in the field. Average depth of tillage operation for each blade was calculated using average formula.

Depth of operation $=\frac{\mathrm{d} 1+\mathrm{d} 2+\mathrm{d} 3+\mathrm{d} 4+\mathrm{d} 5}{5} \mathrm{~mm}$

Where;

$\mathrm{d}=$ Depth $(\mathrm{mm})$,

\section{Forward speed of implement}

Marked $75 \mathrm{~m}$ distance in the grapevine field, time required to cover the marked distance was calculated with the help of stop watch. The forward speed of operation was measured by the following equation (Islam, 2017) [15].

Forward speed $(\mathrm{m} / \mathrm{s})=\frac{D}{t}$

Where;

$\mathrm{D}=$ Distance $(\mathrm{m})$,

$\mathrm{t}=$ time $(\mathrm{s})$,

\section{Theoretical field capacity}

It is maximum possible capacity obtainable at a given speed, assuming the implement is using its full width. It can be defined as the product of work width (W) of implement and speed of operation $\left(V_{f}\right)$. Area covered per unit time denoted in hectare per hour and it is calculated by using formula [13].

Theoretical field capacity (ha/hour) $=\frac{\mathrm{W} \times V_{f} \times 3600}{10000}$

Where,

$\mathrm{W}=$ Rated width of implement (m)

$\mathrm{V}_{\mathrm{f}}=$ Forward speed of implement $(\mathrm{m} / \mathrm{s})$

\section{Actual field capacity}

The number of hectares covered a long period of time. Time required for completing tillage work productive time $\left(T_{p}\right)$ and that lost for other activities such as turning at head handle, blade cleaning when clogging with weeds unproductive time $\left(\mathrm{T}_{\mathrm{c}}\right)$ was recorded with the help of stopwatch and calculated by using formula [13].

$a=\frac{A}{(\mathrm{Tp}+T c)}(\mathrm{ha} / \mathrm{hr})$
Where,

$a=$ Actual field capacity (ha/h)

$\mathrm{A}=$ Area cover ha,

$\mathrm{T}_{\mathrm{p}}=$ Productive time

$\mathrm{T}_{\mathrm{c}}=$ Unproductive time, $\mathrm{h}$

\section{Field efficiency}

The ratio of actual field capacity and theoretical field capacity. It is expressed in per cent and calculated using by following question $[13,16]$.

Field efficiency $=\frac{\text { Actual field capacity }}{\text { Tharotical field capacity }} \times$ 100

\section{Fuel consumption}

To determine the fuel consumption of implement, the fuel tank filled with known quantity of fuel and marked on the graduated scale and interculture operation performed in the field of grapevine for period of one hour. After the interculture operation, stop the engine and the fuel tank was refilled at the marked level before experimentation. Amount of fuel needed to refill the fuel tank up to marked level after one hour of interculture operation.

Fuel consumption was calculated by using standard method as follow

$\mathrm{F}_{\mathrm{c}}=\frac{q}{t}$

Where;

$\mathrm{F}_{\mathrm{c}}=$ Fuel consumption $(\mathrm{L} / \mathrm{hr})$

$\mathrm{q}=$ Quantity of fuel (L)

$\mathrm{t}=$ Consumption time $(\mathrm{min})$

\section{Operational cost}

The sum of fixed cost and variable cost is known as "operational cost". Variable cost was calculated by considering repair and maintenance $50 \%$ of initial cost, fuel cost per hour, lubrication cost $15 \%$ of fuel cost and operator wages for interculture implement during its working. Fixed cost was calculated by considering the depreciation, interest on capital, insurance and housing 2-3\% of initial cost [17].

Depreciation 5 year life and 10\% salvage

value $=\frac{\text { Purchase value-Salvage value }}{\text { machine life }}$ 
Investment for calculating interest at $6 \%$ $=\frac{\text { cost of new machine }+ \text { salvage value }}{2}$

\section{Results and discussion}

Present experiment was conducted to test different shapes of intercultural blades. Data was recorded for different parameters; weeding efficiency, plant damage, actual field capacity, theoretical field capacity, depth of operation, forward speed of implement, field efficiency, fuel consumption and operational cost and analyzed statistically using Randomize Complete Block Design (RCBD) at 5\% level of probability. Results for various parameters are discuss as.

\section{Weeds efficiency $(\%)$}

Mean value of weeding efficiency (Table 1) of implement differ with different shape of blade and days after bud formation. Days after bud formation with different time interval $(25,45 \&$ 60) data of weeding efficiency was calculated $(79.13,79.21 \& 81.90 \%)$ in experimental field during operation of interculture implement. Weeding efficiency was maximum $(81.90 \%)$ at $60 \mathrm{DABF}$ as soil have optimum moisture content for weeding operation due to rain fall and on other side weeding efficiency decrease $79.15 \& 79.29 \%$ at $25 \& 45 \mathrm{DABF}$ as field have excessive weeds. For different shape of blades ( $\mathrm{C}, \mathrm{J}, \mathrm{L} \& \mathrm{R})$ values of weeding efficiency was recorded as 79.13, 74.21, 88.93 $\& 79.20 \%$ respectively. Weeding efficiency of L-shape blade was recorded maximum (83.93 $\%$ ) as compare to other shape of blades. Lshape blade pulverize soil mix the residue in better way due to its shape. However, in Jshape blade minimum weeding efficiency (74.21\%) was observed as it less pulverize soil mostly use for disturbed the soil surface due to its shape. Mean value of treatment for weeding efficiency shows that $\mathrm{C}$ and $\mathrm{R}$ shape blades are non-significant with each other while $\mathrm{J}$ and Lshape blade are significant with each other. However weeding efficiency in the three experiment $(25,45 \& 60)$ DAS were significantly differ with each other at $5 \%$ level of probability. The results are in line with the finding of other researchers who found $78 \%$ weeding efficiency for power weeder [18].

\section{Depth of operation ( $\mathrm{mm}$ )}

Mean values of depth of operation for different shapes of blade and days after bud formation on depth of operation intercultural implement are shown in (Table 2). Days after bud formation $(25,45 \& 60)$ the depth of operation of interculture implement was minimum (46.15 $\mathrm{mm})$ at 25 DAS because the soil has undisturbed surface for weeding operation as compare to other days ( $45 \& 60)$. The average depth of operation was increase $(47.3 \& 49$ $\mathrm{mm})$ at $(45 \& 60)$ DABF because soil surface has already disturbed after first weeding operation. For different shape of blades $(C, J, L$ $\&$ R) value of depth of operation were calculated (47.60, 40.13, $52.60 \& 49.60 \mathrm{~mm})$. The depth of operation of L-shape blade was maximum $(52.60 \mathrm{~mm})$, while $\mathrm{J}$-shape blade was found minimum $(40.13 \mathrm{~mm})$ depth of operation. Mean value of treatment for depth of operation shows that $(\mathrm{C}, \mathrm{J}, \mathrm{L}$ and $\mathrm{R})$ shape blades are significantly differ with each other at $5 \%$ level of probability. However weeding efficiency in the three experiment with different time interval $(25,45 \& 60)$ DABF were non-significant with each other at $5 \%$ level of probability. The results are parallel with the finding of other researchers who found depth of operation of small-scale power weeders $(40 \mathrm{~mm})$ [13].

Table 1. Effect of different shape of blades with different time interval after bud formation on weeding efficiency $(\%)$

\begin{tabular}{|c|c|c|c|c|}
\hline Shapes of Blades & 25 DABF & 45 DABF & 60 DABF & Mean \\
\hline $\mathbf{C}$ & $78.1 \mathrm{de}$ & $78.6 \mathrm{~d}$ & $80.8 \mathrm{c}$ & $\mathbf{7 9 . 1} \mathbf{~ b}$ \\
\hline $\mathbf{J}$ & $72.2 \mathrm{f}$ & $73.6 \mathrm{f}$ & $76.8 \mathrm{e}$ & $\mathbf{7 4 . 2} \mathbf{c}$ \\
\hline $\mathbf{L}$ & $88.3 \mathrm{~b}$ & $88.4 \mathrm{~b}$ & $90.4 \mathrm{a}$ & $\mathbf{8 8 . 9} \mathbf{a}$ \\
\hline $\mathbf{R}$ & $78.4 \mathrm{de}$ & $79.0 \mathrm{~d}$ & $79.6 \mathrm{~cd}$ & $\mathbf{7 9 . 2} \mathbf{~ b}$ \\
\hline Mean & $\mathbf{7 9 . 1 5} \mathbf{b}$ & $\mathbf{7 9 . 2 9} \mathbf{b}$ & $\mathbf{8 1 . 9} \mathbf{a}$ & \\
\hline
\end{tabular}


Table 2. Effect of different shape of blades with different time interval after bud formation on depth of operation $(\mathrm{mm})$

\begin{tabular}{|c|c|c|c|c|}
\hline Shapes of Blades & 25 DABF & 45 DABF & 60 DABF & Mean \\
\hline C & $49.40 \mathrm{cde}$ & $47.40 \mathrm{ef}$ & $46.10 \mathrm{f}$ & $\mathbf{4 7 . 6 0} \mathbf{c}$ \\
\hline $\mathbf{J}$ & $42.48 \mathrm{e}$ & $40.20 \mathrm{gh}$ & $37.80 \mathrm{~h}$ & $\mathbf{4 0 . 1 3} \mathbf{~ d}$ \\
\hline $\mathbf{L}$ & $54.15 \mathrm{a}$ & $51.60 \mathrm{abc}$ & $52.20 \mathrm{ab}$ & $\mathbf{5 2 . 6 0} \mathbf{a}$ \\
\hline $\mathbf{R}$ & $50.80 \mathrm{bcd}$ & $50.0 \mathrm{bcde}$ & $48.60 \mathrm{def}$ & $\mathbf{4 9 . 6 0} \mathbf{b}$ \\
\hline Mean & $\mathbf{4 9 . 3 9} \mathbf{a}$ & $\mathbf{4 7 . 3 0} \mathbf{a}$ & $\mathbf{4 6 . 1 5} \mathbf{a}$ & \\
\hline
\end{tabular}

\section{Fuel consumption (liter/hr)}

Effects of different shape of blade and days after bud formation on fuel consumption in grapevine field were showed in (Table 3). Days after bud formation $(25,45 \& 60)$ the fuel consumption was calculated during the field operation of small scale interculture implement (1.22, $1.24 \& 1.29 \mathrm{liter} / \mathrm{hr})$. The fuel consumption was maximum (1.29 liter/hr) at 60DABF perhaps the soil lost moisture content after weeding operation $25 \& 45$ DABF and minimum fuel consumption (1.22 liter/hr) at $25 \mathrm{DABF}$. The fuel consumption was recorded (1.24 liter/hr) at 45 DABF. For different shape of blades (C, $\mathrm{J}, \mathrm{L} \& \mathrm{R}$ ) fuel consumption was recorded in field $(1.23,1.25,1.27 \& 1.26 \mathrm{liter} / \mathrm{hr})$. The fuel consumption of L-shape blades was maximum (1.27 liter/hr) as compare to other shape of blade. The value of fuel consumption decrease for $\mathrm{C}$-shape blade was recorded (1.23 liter/hr) while $\mathrm{J}$-shape blade was calculated $(1.25 \mathrm{liter} / \mathrm{hr})$ and fuel consumption value was recorded of $\mathrm{R}$-shape blade (1.26 liter/hr). Mean value of treatment for fuel consumption shows that $(C \& L)$ shape blades are non-significant with each other while ( $\mathrm{J}$ and $\mathrm{R}$ ) are significantly differ with each other at $5 \%$ level of probability. However weeding efficiency in the three experiment with different time interval $(25$, $45 \& 60)$ DABF were significantly differ with each other at $5 \%$ level of probability. The results are matching with the finding of other researchers who find fuel consumption of self-propeller rotary weeder in grapevine was $1.68(\mathrm{Liter} / \mathrm{hr})[19]$.

Table 3. Effect of different shape of blades with different time interval after bud formation on fuel consumption (liter/hr)

\begin{tabular}{|c|c|c|c|c|}
\hline Shapes of Blades & $\mathbf{2 5}$ & $\mathbf{4 5}$ & $\mathbf{6 0}$ & Mean \\
\hline $\mathbf{C}$ & $1.19 \mathrm{e}$ & $1.22 \mathrm{e}$ & $1.27 \mathrm{~b}$ & $\mathbf{1 . 2 3} \mathbf{~ b}$ \\
\hline $\mathbf{J}$ & $1.26 \mathrm{bc}$ & $1.26 \mathrm{bc}$ & $1.27 \mathrm{a}$ & $\mathbf{1 . 2 5} \mathbf{~ a}$ \\
\hline $\mathbf{L}$ & $1.25 \mathrm{f}$ & $1.27 \mathrm{e}$ & $1.32 \mathrm{~b}$ & $\mathbf{1 . 2 7} \mathbf{~ b}$ \\
\hline $\mathbf{R}$ & $1.23 \mathrm{a}$ & $1.25 \mathrm{de}$ & $1.28 \mathrm{ab}$ & $\mathbf{1 . 2 6} \mathbf{a}$ \\
\hline Mean & $\mathbf{1 . 2 2} \mathbf{b}$ & $\mathbf{1 . 2 4} \mathbf{c}$ & $\mathbf{1 . 2 9} \mathbf{a}$ & \\
\hline
\end{tabular}

\section{Actual field capacity (ha/hr)}

Mean values of actual field capacity (Table 4) for different shape of blade and days after bud formation on actual field capacity of grapevine are shown in (Table 4). Days after bud formation $(25,45 \& 60)$ the value of actual field capacity was recorded in a field $(0.1034$, $0.1057 \& 0.1089 \mathrm{ha} / \mathrm{hr}$ ). The actual field capacity was maximum $(0.1089 \mathrm{hec} / \mathrm{hr})$ at 60
DABF. While the actual field capacity decrease (0.1053 ha/hr) at $45 \mathrm{DABF}$ was recorded and minimum actual field capacity $(0.1030 \mathrm{ha} / \mathrm{hr})$ at 25 DABF. For different shape of blades (C, J, $\mathrm{L} \& \mathrm{R}$ ) values of actual field capacity was recorded in field $(0.1045,0.0940,0.1166$ $\& 0.1102 \mathrm{ha} / \mathrm{hr})$. The actual field capacity of Jtype blade was minimum $(0.0940 \mathrm{ha} / \mathrm{hr})$, while maximum value of $\mathrm{L}$-shape blade was recorded 
$(0.1166 \mathrm{hec} / \mathrm{hr})$. Mean value of treatment for actual field capacity shows that (C, J, L \& R) shape blades are significantly differ with each other. However actual field capacity in the three experiment $(25,45 \& 60)$ DABF were significantly differ with each other at $5 \%$ level of probability. The results are in line with the findings of other researchers who fined actual field capacity of self-propelled rotary power weeder and observed 0.092, 0.08, $0.096 \mathrm{ha} / \mathrm{hr}$ at forward speed of 2.3, 2.0 and $2.4 \mathrm{~km} / \mathrm{hr}$ in tomato, yard long bean and okra crops, respectively [20].

Table 4. Effect of different shape of blades with different time interval after bud formation on actual field capacity (ha/hr)

\begin{tabular}{|c|c|c|c|c|}
\hline Shapes of Blades & 25 DABF & 45 DABF & 60 DABF & Mean \\
\hline C & $0.1070 \mathrm{~d}$ & $0.1054 \mathrm{de}$ & $0.1010 \mathrm{ef}$ & $\mathbf{0 . 1 0 4 5} \mathbf{~ c}$ \\
\hline $\mathbf{J}$ & $0.0968 \mathrm{fg}$ & $0.0932 \mathrm{gh}$ & $0.0920 \mathrm{~h}$ & $\mathbf{0 . 0 9 4 0 ~ d}$ \\
\hline $\mathbf{L}$ & $0.1162 \mathrm{a}$ & $0.1166 \mathrm{c}$ & $0.115 \mathrm{abc}$ & $\mathbf{0 . 1 1 6 6} \mathbf{a}$ \\
\hline $\mathbf{R}$ & $0.1134 \mathrm{bc}$ & $0.1116 \mathrm{c}$ & $0.1056 \mathrm{de}$ & $\mathbf{0 . 1 1 0 2} \mathbf{b}$ \\
\hline Mean & $\mathbf{0 . 1 0 8 9} \mathbf{a}$ & $\mathbf{0 . 1 0 5 7} \mathbf{b}$ & $\mathbf{0 . 1 0 3 4} \mathbf{c}$ & \\
\hline
\end{tabular}

\section{Field efficiency $(\%)$}

Table 5 showed that Mean values of different shapes of blade and days after bud formation on field efficiency of interculture implement in grapevine field were found. Days after bud formation $(25,45 \& 60)$ the data was calculated in a field during operation of interculture implement $(81.60,84.80 \& 86.15$ $\%)$. The field efficiency was minimum $(81.60$ $\%)$ at 25 DABF because the first time implement operated in weeding field where weeds were not completely removed and soil was not completely pulverized therefore the field efficiency was less as compare to other days. At second time field efficiency increase $(83.90 \%)$ at 45 DABF likewise field efficiency maximum at 60 DABF because weeding efficiency and soil pulverized increase. For different shape of blades $(\mathrm{C}, \mathrm{J}$, L \& R-) values field efficiency was recorded in field $(82.66,74.53,94.53 \& 87.01 \%)$. The field efficiency of J-shape blade was observed minimum $(74.53 \%)$, while the maximum value of field efficiency was recorded of L- shape blade $(92.53 \%)$. Mean value of treatment for field efficiency shows that $(\mathrm{C}, \mathrm{J}, \mathrm{L} \& \mathrm{R})$ shape blades are significantly differ from each other. However, field efficiency in the three experiment with different time interval $(25$, $45 \& 60)$ DABF were significant differ with each other at $5 \%$ level of probability. Research results are not in line with the finding of other researchers who found the field efficiency of power weeder $83 \%$ [18].

Table 5. Effect of different shape of blades with different time interval after bud formation on field efficiency $(\%)$

\begin{tabular}{|c|c|c|c|c|}
\hline Shapes of Blades & 25 DABF & 45 DABF & 60 DABF & Mean \\
\hline C & $84.60 \mathrm{~d}$ & $82.20 \mathrm{de}$ & $80.20 \mathrm{e}$ & $\mathbf{8 2 . 6 6} \mathbf{c}$ \\
\hline $\mathbf{J}$ & $76.40 \mathrm{f}$ & $74.80 \mathrm{fg}$ & $72.40 \mathrm{~g}$ & $\mathbf{7 4 . 5 3} \mathbf{d}$ \\
\hline $\mathbf{L}$ & $94.20 \mathrm{a}$ & $9340 \mathrm{ab}$ & $90.40 \mathrm{bc}$ & $\mathbf{9 2 . 5 3} \mathbf{a}$ \\
\hline $\mathbf{R}$ & $89.40 \mathrm{c}$ & $88.20 \mathrm{c}$ & $83.40 \mathrm{de}$ & $\mathbf{8 7 . 0 1} \mathbf{b}$ \\
\hline Mean & $\mathbf{8 6 . 1 5} \mathbf{a}$ & $\mathbf{8 4 . 8 0} \mathbf{b}$ & $\mathbf{8 1 . 6 0} \mathbf{c}$ & \\
\hline
\end{tabular}




\section{Operational cost (Rs/ha)}

Effect of different shapes of blade and time interval days after bud formation on operational cost of interculture implement in grapevine field experiment are shown in (Table 6). Days after bud formation (25, 45 $\& 60)$ the data was calculated for small scale interculture implement in a field $(2232,2314$ \& $2642 \mathrm{Rs} / \mathrm{ha}$ ). The minimum operational cost was calculated (2232Rs/ha) at $25 \mathrm{DABF}$ because the time required for weeding and fuel consumption was less as compare to other days 45 and 60 , on the other side operational cost were increase (2314 Rs/ha) at 45 DABF. Similarly, value of operational cost was maximum (1070 Rs/ha) at 60 DABF. For different shape of blades (C, J, L $\&$ R) fuel consumption was calculated in field (2393, 2476, $2346 \& 2378 \mathrm{Rs} / \mathrm{ha})$. The operational cost of L- shape blade was minimum (2346 Rs/ha) as compare to other shape of blade due to its shape. The value of operational cost of C-shape blade was recorded (2393 Rs/ha), while the maximum value of operational cost of $\mathrm{J}$-shape blade was calculated $(2467 \mathrm{Rs} / \mathrm{ha})$ and value of operational cost was calculated of R- shape blade (2378 Rs/ha). Mean value of treatment for operational cost shows that $(\mathrm{C}, \mathrm{J}, \& \mathrm{R})$ shape blades are non-significant with each other. However operational cost in the three experiment $(25, \& 45)$ DABF were found non-significant with each other at $5 \%$ level of probability. Research results are contradictory with scientists who find the operational cost be Rs 1469 per ha, which was $41.25 \%$ less as related to manual weeding of Rs 2500 per ha [18].

Table 6. Effect of different shape of blades with different time interval after bud formation on operational cost (Rs/ha)

\begin{tabular}{|c|c|c|c|c|}
\hline Shapes of Blades & 25 DABF & 45 DABF & 60 DABF & Mean \\
\hline C & $2200 \mathrm{e}$ & $2292 \mathrm{de}$ & $2687 \mathrm{~b}$ & $\mathbf{2 3 9 3} \mathbf{b}$ \\
\hline $\mathbf{J}$ & $2237 \mathrm{de}$ & $2363 \mathrm{~d}$ & $2803 \mathrm{a}$ & $\mathbf{2 4 6 7} \mathbf{a}$ \\
\hline $\mathbf{L}$ & $2227 \mathrm{e}$ & $2282 \mathrm{de}$ & $2534 \mathrm{c}$ & $\mathbf{2 3 4 6} \mathbf{b}$ \\
\hline $\mathbf{R}$ & $2264 \mathrm{de}$ & $2324 \mathrm{de}$ & $2549 \mathrm{c}$ & $\mathbf{2 3 7 8} \mathbf{b}$ \\
\hline Mean & $\mathbf{2 2 3 2} \mathbf{b}$ & $\mathbf{2 3 1 4} \mathbf{b}$ & $\mathbf{2 6 4 2} \mathbf{a}$ & \\
\hline
\end{tabular}

\section{Conclusion}

It was concluded from the study that the maximum weed efficiency, depth of operation, theoretical field capacity, actual field capacity, field efficiency, fuel consumption and minimum operational cost was observed in Lshaped intercultural implement. The results of this study indicate that newly-developed implement is most feasible for intercultural operation 1 in grapevine yard. This study is unique in the prospect as it developed a new interculture system for the grapevine field of Pothwar region of Punjab Pakistan. This is first such kind of research work which has been done with significant research narrative for adaptation strategies for country's for poor and small farming community, home gardeners and orchards farms etc. where tractor operated heavy implements are not feasible.

\section{Authors' contributions}

Conceived and designed the experiments: ZU Haq \& MK Nawaz, Performed the experiments: MK Nawaz, Analyzed the data: T Mehmood, A Imran \& MK Shafi, Contributed materials/ analysis/ tools: HM Asam, SR Haidree \& A Qadeer, Wrote the paper: MK Nawaz \& T Mehmood.

\section{Acknowledgments}

I am highly thankful to Dean, Faculty of Agricultural Engineering and Technology, Malik Engineering workshop, Dhudail, Chakwal and Director University Research Farm Koont Chakwal, Pakistan for providing me facilities and infrastructure required during this research. 


\section{References}

1. Manjunatha K, Anantachar M, Prakash KV, Desai BK \& Vijayakumar P (2016). Development and evaluation of tractor operated rotary weeder. Environ Ecol 34(4): 1643-1648.

2. Thorat DS, Shoo PK, Dipankar D \& Asif I (2014). Design and development of ridge profile power weeder. Intl J Agri Eng 51(4).

3. Karnkal US (2013). Design and development of self-propelled weeder for field crops. Intl J Agri Engg 6: 304-310.

4. Aristilde L, Reed ML, Wilkes RA, Youngster T, Kukurugya MA, Katz V \& Sasaki CR (2017). Glyphosate-induced specific and widespread perturbations in the metabolome of soil Pseudomonas species. Front Envir Sci 5: 34.

5. Patange GS, Thokale PJ \& Deshmukh VD (2015). Performance evaluation of selfpropelled rotary weeder. Intl J Agri Eng 8(1): 70-74.

6. Karnkal US (2013). Design and development of self-propelled weeder for field crops. Intl J Agri Engg 6: 304-310.

7. Gavali M \& Satish K (2014). Development of rotary weeder blades by finite element method. Intl J Sci Res Eng Tech 3(6): 941945.

8. Chavan M, Sachin C, Ashutosh R, Piyush S \& Digvijay M (2015). Design and development of weed removal implement. Intl J Res Appl Sci Eng Tech 3(5): 526532.

9. Manjunatha K, Anantachar M, Prakash KV, Desai BK \& Vijayakumar P (2016). Development and evaluation of tractor operated rotary weeder. Environ Ecol 34(4): 1643-1648.

10. Thorat DS, Shoo PK, Dipankar D \& Asif I (2014). Design and development of ridge profile power weeder. Intl J Agri Eng 51(4).
11. Dhruwe NK (2018). Development of selfpropelled rotary tiller cum inters row weeder. Trends in Biosci 11(5): 694-697.

12. Islam AS, Islam MT, Islam MS, Rahman AL \& Rahman MA (2017). Performance evaluation of BRRI power weeder for low land rice (Oryza sativ L.) cultivation. The Agri 15(1): 40-48.

13. Haque, ME, Meisner CA, Hossain I, Justice S, Rashid MH \& Sayre KD (2004). Two wheel tractor operated zero till seed drill: A viable crop establishment and resource conservation option. CIGR International Conference Beijing, China. 11-14 October 2004, (January), 203-209.

14. Remesan R, Roopesh MS, Remya N \& Preman PS (2007). Wet land paddy weeding- A comprehensive comparative study from south India. Agri Eng Intl 11: 9.

15. Hunt D (1995). Farm power and machinery management ( $9^{\text {th }}$ Ed.). Lowa State University Press. Ames, IA, USA.

16. Hegazy RA, Abdelmotaleb IA, Imara ZM \& Okasha MH (2014). Development and evaluation of small-scale power weeder. Intl J Agri Eng 31(3): 703-728.

17. Jeevarathinam A \& Velmurugan C (2014). Design modification and analysis of rotavator blade. J Mech Civl Eng 43-50.

18. Kepner RA, Bainer R \& Barger EI (2005). Principal of farm machinery. Pub. John Wiley and Sons, NY, USA, pp 32-38.

19. Patange GS, Thokale PJ \& Deshmukh VD (2015). Performance evaluation of selfpropelled rotary weeder. Intl J Agri Eng 8(1): 70-74.

20. Tewari VK, Chandel NS, Vidhu KP \& Tripathi H (2014). Performance evaluation and scope of adoption of rotary power weeder in vegetable crops. Agri Eng Today 38(3): 10-14. 